\title{
Proximate Analysis and Phytochemical Screening of Irvingia Gabonensis (Agbono Cotyledon)
}

\author{
Don Lawson D Chioma* \\ Department of Science laboratory Technology, School of Science and Technology, Nigeria
}

Received: May 31, 2018; Published: June 14, 2018

*Corresponding author: Don Lawson D Chioma, Department of Science laboratory Technology, School of Science and Technology, Port Harcourt Polytechnic Nigeria

\begin{abstract}
Chemical analyses on agbono cotyledon was carried out in order to identify the various proximate(s) that constitute the agbono cotyledon as well as to establish also the forms of phytochemicals present in agbono cotyledon by simple extraction processes using three different solvents (petroleum ether, ethanol and distilled water). The results from the analysis showed that agbono cotyledon displayed the following proximates; carbohydrates, protein, lipids (fats and oil), moisture and ash. The later were established to be responsible for agbono cotyledon's drawability, colour, taste and aroma when used as condiment. However, values of $0.17 \%, 0.13 \%, 80.41 \%, 19.14 \%$ and $0.15 \%$ were obtained for the petroleum ether extract; while the data; $0.25 \%, 0.13 \%, 15.17 \%, 84.31 \%$ and $0.14 \%$ were recorded for the ethanol extract, and then $0.25 \%, 0.35 \%, 4.91 \% .94 .41 \%$ and $0.08 \%$ values were acquired for the distilled water extract with respect to carbohydrates, protein, lipids (fats and oil), moisture and ash contents. Furthermore, the phytochemical tannins, alkaloids, flavonoids, glycosides, phytate, oxalate, saponins and steroids were observed to be present $(+)$, highly present $(++)$, present $(+)$, present $(+)$ absent $(-)$, absent $(-)$, present $(+)$ and absent $(-)$ in the petroleum ether extract, then present(+), present(+), highly present(++), absent(-), absent(-), present(+) and present $(+)$ inthe distilled water extract, but were highly present(++), present $(+)$, present $(+)$, present $(+)$, absent $(-)$, absent $(-)$, present $(+)$ and present $(+)$ in the ethanol extract. The results in all showed that both proximates and phytochemicals were present at different levels in agbono cotyledon.
\end{abstract}

Keywords: Cotyledon; Proximate; Phytochemical; Irvingia; Saponins; Flavonoids; Glycosides; Steroids, Phytate; Oxalate; Kjeldahl Method; Brachystegia; Akpalata; Tannins; Alkaloids; Agbono Cotyledon

\section{Introduction}

Soup is a tasty, popular food that is nutritious, wholesome and stimulates the human appetite. Soup thickening usually improves its taste, but most significant is the nutritional value of foods been thickened. In fact, every time the soup is thickened its nutritive value is determined by the ingredients of the thickener added to it [1]. Generally, condiments which when added to an aqueous mixture increases its viscosity without substantially modifying its other properties, such as taste, aroma and drawability are termed soup thickeners or thickening agents. Thickeners provide the soup body, increase its stability and improve suspension of added ingredients Collins \& Harry. Food thickening can be important for people facing medical issues with chewing or swallowing, as foods with a thicker consistency can reduce the chances of choking or of inhalation of liquids or foods particles, which can lead to aspiration pneumonia [1]. The use of thickeners such as Afzelia Africa (Akpalata), Brachystegia (Achi/ofor), Irvingia gabonensis var excels (ugiri/agbono) in soup preparations requires more investigations into the nature and compositions of the constituents so as to ascertain their actual nutritional essence.
Agbono (Irvingia gabonensis) frequently called "African mango" is a native forest tree fitting to the group of plants classified as "non-timber forest products" (NTFPs), Festus and Ibor, and the family of Irvingiaceace. Usually of two species Irvingia gabonensis and Irvingia excelsa [2], which are found in normal forest, family gardens and fields Orji, 2006.Irvingia gabonensis fruits, can be eaten fresh with their kernels collected from wild forest (60\%) and from the family gardens (10\%) and fields (30\%). Researchers reports that different families depend on the fruit collection (consumption and for sale) enterprise for survival [3-5]. The kernel of Irvingia gabonensis contain $54-67 \%$ of fatty matter and serves as condiment used in thickening and flavouring soup [5]. The more Irvingia gabonensis in soup, the more acceptable it becomes [6-8]. This work is hence intended to investigate the drawability and rancidity of agbono soup identifying the various proximate(s) and the phytochemicals contained in agbono cotyledon.

\section{Materials and Methods}

Preparation of the Agbono Cotyledon: The agbono (Irvingia gabonensis) cotyledon was bought from Iwofe daily market (4 
cups) taken to the Chemistry Department laboratory, Ignatius Ajuru University of Education, Rumuolumeni, Port Harcourt, properly cleaned using kitchen knife, and afterwards ground to powder using mortar and pestle. Three fractionating columns were adopted to extract the wax of agbono (Irvingia gabonensis) cotyledon using ethanol, petroleum ether and distilled water as solvents.

Petroleum Ether Extract: A 100g of the ground agbono (Irvingia gabonensis) cotyledon was weighed and gradually transferred into a soxhlet extractor using spatula. The cotyledon was submerged with petroleum ether $(60-80 \%, 400 \mathrm{~mL})$. The soxhlet extractor set up with its mixture content was heated using heating mantle to enhance full extraction of the agbono wax.

Ethanol Extract: To $450 \mathrm{~mL}$ ethanol solution in a soxhlet extractor, $100 \mathrm{~g}$ of the ground Irvingia gabonensis was transferred gradually with the aid of a spatula and the wax were fully extracted on a heating mantle.

Distilled Water Extract: The same processes as explained above were adopted with slight modifications.Distilled water $(300 \mathrm{~mL})$ was used as the extraction solvent $[9,10]$.

\section{Methods of Analysis}

After all extraction processes, the three extracts were analyzed for proximate and phytochemical compositions at the Plant Anatomy and Physiology Research Laboratory, University of Port-Har-

Table 1: Proximate Analysis of Agbono Cotyledon. court. The cotyledon was analyzed proximate contents using the Furnace method (for ash content); air oven method (for moisture content); Cleg anthrone method (for carbohydrate content); Kjeldahl method (for protein content); Phase separation method (for lipids content), while the phytochemical composition was determined through qualitative analysis [11-13].

\section{Results and Discussions}

Table 1 revealed that Irvingia gabonensis contains the following proximate contents; carbohydrate, protein, lipids, moisture and ash at different quantities of $0.17 \%, .80 .41 \%, 19.14 \%, 0.15 \%$ and $0.13 \%$ respectively for the petroleum ether extract. The proximate contents can be represented as lipids $>$ moisture $>$ carbohydrate $>$ ash $>$ protein. Also, the proximate contents for the ethanol extract displayed values of $84.31 \%, 15.17 \%, 0.25 \%, 0.14 \%$ and $0.13 \%$ for moisture, lipids, carbohydrate, ash and protein respectively. It can also be represented as; Moisture $>$ lipids $>$ carbohydrate $>$ ash $>$ protein. The distilled water extract presented the content of the moisture, lipids, protein, carbohydrate and ash as $94.41 \%, 4.91 \%$, $0.35 \%, 0.25 \%$ and $0.08 \%$ which can be represented in the order moisture $>$ lipids $>$ protein $>$ carbohydrate $>$ ash.Generally, the carbohydrate contents were lesser in content compared to other proximate contents. On the other hand, the protein content for the petroleum ether extract equaled that of ethanol extract, while the content obtained from the distilled water extract was greater than that of extracts [13-15].

\begin{tabular}{|c|c|c|c|}
\hline Proximate Contents & Petroleum Ether Extract (\%) & Ethanol Extract (\%) & Distilled Water Extract (\%) \\
\hline Carbohydrate & 0.17 & 0.25 & 0.25 \\
\hline Protein & 0.13 & 0.13 & 0.35 \\
\hline Lipids (fat and oil) & 80.41 & 15.17 & 4.91 \\
\hline Moisture & 19.14 & 84.31 & 94.41 \\
\hline Ash & 0.15 & 0.14 & 0.08 \\
\hline Fibre & Nil & Nil & Nil \\
\hline Total & 100.00 & 100.00 & 100.00 \\
\hline
\end{tabular}

Apparently, the lipid (fat and oil) contents obtained for the petroleum ether extract was greater than that of ethanol extract, while that of the ethanol extract displayed greater content than that of the distilled water extract. Similarly, the moisture content for the distilled water extract was higher compared to the ethanol extract, though the ethanol extract content was larger than that of the petroleum ether extract content. Finally, the ash content for the petroleum ether extract stood greater than the ethanol extract Table 2: Phytochemical Analysis of Agbono Cotyledon. content, whereas that of the ethanol extract remained bigger compared to the distilled water extract content.Critical examination of Table 2 indicated that the two major phytochemical compositions of Irvingia gabonensis are tannins and alkaoids which encompasses bioactive secondary metabolites that may find useful applications in medicine and pharmacology. Other phytochemicals determined include saponins, flavonoids, glycosides, steroids, phytate and oxalate.

\begin{tabular}{|c|c|c|c|}
\hline Phytochemicals & Petroleum ether extract & Ethanol extract & Distilled water extract \\
\hline Tannins & + & + & ++ \\
\hline Alkaloids & ++ & ++ & + \\
\hline Flavonoids & + & - & + \\
\hline Glycoside & + & - & + \\
\hline Phytate & - & + \\
\hline
\end{tabular}




\begin{tabular}{|c|c|c|c|}
\hline Oxalate & - & - & - \\
\hline Saponins & + & + & + \\
\hline Steroids & - & + & + \\
\hline
\end{tabular}

Note: Key: $(+)=$ Present; $(++)$ = Highly Present, $(-)$ Absent

The obtained data revealed that tannins was present (+) in petroleum ether extract, highly present $(++)$ in ethanol extract, and averagely present $(+)$ in the distilled water extract. However that of alkaloids was extremely present $(++)$ in petroleum ether extract, normally present $(+)$ in ethanol extract, and averagely present $(+)$ in distilled water extract. Likewise, the result showed that flavonoid was just present $(+)$ in petroleum ether extract, present $(+)$ in ethanol extract and highly present $(++)$ in distilled water extract; glycosides was observed present $(+)$ in the petroleum ether extract, normally present $(+)$ in ethanol extract and completely absent $(-)$ in the distilled water extract. The phytate and oxalate were also completely absent (-) in the three (petroleum ether, ethanol and absent distilled water) extracts. However, saponins were noticed averagely present $(+)$ in all the (petroleum ether, ethanol and absent distilled water) extracts, while steroids were absent (-) in petroleum ether extract, present (-) in ethanol extract and averagely present $(+)$ in distilled water extract.

Summarily, this work has established that various proximates make up the agbono cotyledon (Irvingia gabonensis). The work also showed that phytochemicals constitute the compositions of Irvingia gabonensis. The obtained results has it that Irvingia gabonensis contains bioactive secondary metabolites (tannins and alkaloids) such as; flavonoids, saponins, glycosides, steroids, phytate and oxalate; that both the proximate and phytochemical contributes to its drawability, aroma, taste and colour; and rancidity when used to prepare soup; the moisture and ash (water) contents were solely responsible for its drawability; the lipids (fat and oil) contents gives rise to its colour; the protein content backs majorly its taste; and the carbohydrate contents were responsible to its aroma. This work recommends that agbono should be consumed by everybody especially people that are fat, people that are suffering from diabetes and people that have excess cholesterol in their body [16-18].

\section{References}

1. Agbor LON (1994) Marketing trends and potential for irvingia gabonensis products in Nigeria. Paper presented at (ICRAF-IIA) conference on irvingia gabonensis Ibadan Nigeria.

2. Akubor PI (1996) The sustainability of African bush mango juice for wine production. Plant, foods, human nutrition 49: 213-219.

3. Ayuk ET, Duguma B, Franzel S, Kengue J, Mollet M, et al. (1999) Uses, management and economic potential of irvingia gabonensis in the humid lowlands of Cameroon. Forest ecology and management 113: 1-9.

4. Chinaka C, Obiefuna JC (1999) Production and utilization of "Ogbono" (irvingia gabonensis). Extension Bulletin No. 140, Horticulture series No. 4 National Agricultural Extension and Research Liason Services, Federal Ministry of Agriculture and Water Resources, Ahmadu Bello University Zaria Nigeria.
5. Chukwuki CO (2006) Factor productivity and technical efficiency in cassava - based food crop. Production system in Delta State Nigeria. Ph.D. Dissertation Delta State University Abraka Nigeria.

6. Ejiofor MAN (1994) Nutritional Values of Ogbono (Irvingia gabonensis var. excelsa). Paper presented at the international council for research in Agroforestry gabonensis. Ibadan, Nigeria.

7. Fernandez - Armesto F (2002) A History of food, near a thousand tables. Free press, New York, USA.

8. Festus C, Nwala L (2012) Extraction and procession of agbono cotyledon for long shel-life. Academic Research International 2(1): 139-145.

9. Harris DJ (1996) A revision of the Irvingiaceace in Africa, Bulletin du Jardin Botanique National de Belgique 65(1-2): 55-64.

10. Iwu MM (1993) Handbook of medicinal plants. BOCA Raton. CRC Press, USA

11. Ladipo DO, Boland DJ (1994) Trade in Irvingia gabonensis kernels. In: DO Ladipo and DJ Boland, (Eds.), Proceedings of the international workshop on Irvingia gabonensis in West Africa. International Center for Research in Agro Forestry (ICRAF) Nairobi Kenya.

12. Ladipo DO (1998) Harvesting of irvingia gabonensis and irvingia wombulu in Nigeria forests, potentials for the development of sustainable system. Centre for Environment, Renewable Natural Resources management, Research and Development (CENRAD) Ibadan Nigeria, West Africa.

13. Ladipo DO, Foundoun JM, Ganga N (1996) Domestication of bush mango (Irvingia spp). Some exploitable intraspecfic variations in West and central Africa. In RRB Leakay, AB Temu, M Melynk, P Vantomme (Eds.). Proceedings of the FAO/ICRAF_IUFRO International Conference on Domestication and Commercialization of Non-timber forest products in Agro-Forestry systems 9: 297.

14. Matos L, Nzikou JM, Matouba E, PandzouYembe V, Mapepoulou TG, et al. (2009) Studies of Irvingia gabonensis seeds kernels. Oil technological applications Pak J Nutrition 8: 151-157.

15. Ngondi JI, Oben JE, Minka SR (2005) The effect of irvingia gabonensis seeds on body weight and blood lipids of obese subjects in Cameroon. Lipids in health and disease 4: 12 .

16. Okafor JC (1974) Varietal delimitation in Irvingia gabonensis (Irvingiaceace). Nigeria Journal of Forestry 4: 80-87.

17. Ofafor JC, Omorrondion FI, Amaza F (1994) Non-timber forest products. Draft report prepared for the national Tropical Forestry Action Programme (NTFAP). Forestry Management Evaluation and Cooperation Unit (FORMECU) Federal Department of Forestry Abuja Nigeria.

18. Okolo CO (1994) Industrial potential of various irvingia gabonensis products such as oil, ogbono and juice, Paper presented to the (ICRAFIITA) Conference on ilrvingia gabonensis. ibadan Nigeria.

19. Oloyede OI (2005) Chemical profile of Unripe pulp of carica papaya. Pak J Nutrition 4(6): 379-381. 
(C) (i) This work is licensed under Creative Submission Link: https://biomedres.us/submit-manuscript.php

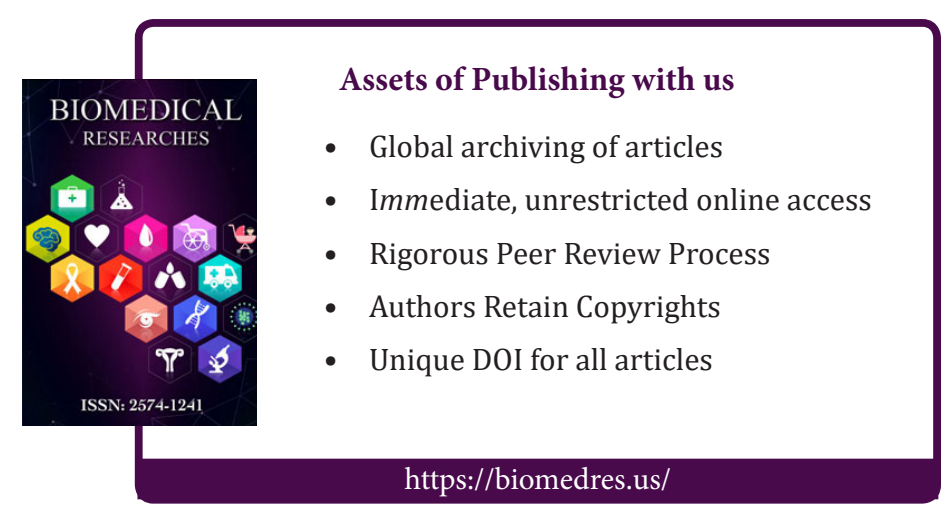

